\title{
Radiosensitization of HSF-1 Knockdown Lung Cancer Cells by Low Concentrations of Hsp90 Inhibitor NVP-AUY922
}

\author{
Annett Kühnel ${ }^{1,2, \dagger}{ }^{\text {, Daniela Schilling }}{ }^{1,2, \dagger}$, Stephanie E. Combs ${ }^{1,2,3}$, Bernhard Haller ${ }^{4}$, \\ Melissa Schwab ${ }^{5}$ and Gabriele Multhoff $1,5, *$ (D) \\ 1 Department of Radiation Oncology, Klinikum rechts der Isar, Technische Universität München (TUM), \\ Ismaninger Straße 22, 81675 Munich, Germany; annett.kuehnel@tum.de (A.K.); \\ daniela.schilling@tum.de (D.S.); stephanie.combs@tum.de (S.E.C.) \\ 2 Institute of Radiation Medicine (IRM), Department of Radiation Sciences (DRS), Helmholtz Zentrum \\ München, Ingolstädter Landstraße 1, 85764 Neuherberg, Germany \\ 3 Deutsches Konsortium für Translationale Krebsforschung (DKTK), Partner Site Munich, \\ 81675 Munich, Germany \\ 4 Institute for Medical Informatics, Statistics and Epidemiology, Technische Universität München, \\ Klinikum rechts der Isar, Ismaningerstr. 21, 81675 Munich, Germany; bernhard.haller@mri.tum.de \\ 5 Center for Translational Cancer Research, Technische Universität München (TranslaTUM), Klinikum rechts \\ der Isar, Einsteinstr. 25, 81675 Munich, Germany; mellissa.schwab@tum.de \\ * Correspondence: Gabriele.multhoff@tum.de; Tel.: +49-89-4140-4514; Fax: +49-89-4149-4299 \\ + Shared first authorship.
}

Received: 10 September 2019; Accepted: 27 September 2019; Published: 28 September 2019

\begin{abstract}
The inhibition of heat shock protein 90 (Hsp90) a molecular chaperone for multiple oncogenic client proteins is considered as a promising approach to overcome radioresistance. Since most Hsp90 inhibitors activate HSF-1 that induces the transcription of cytoprotective and tumor-promoting stress proteins such as Hsp70 and Hsp27, a combined approach consisting of HSF-1 knockdown (k.d.) and Hsp90 inhibition was investigated. A specific HSF-1 k.d. was achieved in H1339 lung cancer cells using RNAi-Ready pSIRENRetroQ vectors with puromycin resistance. The Hsp90 inhibitor NVP-AUY922 was evaluated at low concentrations-ranging from 1-10 nM-in control and HSF-1 k.d. cells. Protein expression (i.e., Hsp27/Hsp70, HSF-1, pHSF-1, Akt, B-actin) and transcriptional activity was assessed by western blot analysis and luciferase assays and radiosensitivity was measured by proliferation, apoptosis (Annexin $\mathrm{V}$, active caspase 3), clonogenic cell survival, alkaline comet, $\gamma \mathrm{H} 2 \mathrm{AX}$, 53BP1, and Rad51 foci assays. The k.d. of HSF-1 resulted in a significant reduction of basal and NVP-AUY922-induced Hsp70/Hsp27 expression levels. A combined approach consisting of HSF-1 k.d. and low concentrations of the Hsp90 inhibitor NVP-AUY922 reduces the Hsp90 client protein Akt and potentiates radiosensitization, which involves an impaired homologous recombination mediated by Rad51. Our findings are key for clinical applications of Hsp90 inhibitors with respect to adverse hepatotoxic effects.
\end{abstract}

Keywords: heat shock factor (HSF-1) knockdown; heat shock proteins 70 and 27; radiosensitization; Hsp90 inhibitor NVP-AUY922; homologous recombination (HR) 


\section{Introduction}

Lung cancer is one of the most commonly diagnosed cancer in Western societies and the leading cause of cancer-related deaths worldwide [1,2]. Despite novel therapeutic approaches including immune checkpoint inhibitor blockade to which only a proportion of patients showed beneficial responses, the 5-year survival rate of late stage tumor diseases remains poor with approximately $15 \%[3,4]$. Radio- and chemoresistance of pulmonary tumor cells is a major limiting factor for a favorable clinical outcome. Therefore, there is a high unmet medical need for combined therapeutic approaches that significantly improve the radiosensitivity of lung cancer cells.

The heat shock proteins Hsp90, Hsp70, and Hsp27 and the transcription factor heat shock factor-1 (HSF-1) are frequently overexpressed in many tumor cell types [5-7], including lung carcinoma. Elevated HSP levels contribute to a malignant transformation and mediate resistance to chemo- and radiotherapy by interfering with apoptotic signaling pathways [8,9]. Hsp90 is an attractive therapeutic target [10-14] and its inhibition affects many oncogenic driver proteins, which are involved in cell cycle regulation, apoptosis, and DNA repair [15-17]. High concentrations of the Hsp90 inhibitor NVP-AUY922 can increase radiosensitivity of tumor cells [14,18]. Apart from these positive effects, the inhibition of Hsp90 induces the release of HSF-1 from the Hsp90 complex and thereby stimulates the transcription of the cytoprotective chaperones Hsp70 and Hsp27 [19-27]. Due to the anti-apoptotic activities of Hsp70 and Hsp27 that promote tumor cell survival, the combined effects of an HSF-1 and Hsp90 inhibition were assessed on the radiosensitivity of H1339 cells.

\section{Methods}

\subsection{Reagents and Treatment}

A stock solution (10mM) of NVP-AUY922 (Novartis, Basel, Schweiz) was prepared in 100\% DMSO and further diluted in PBS. A vehicle control with the respective amount of DMSO was diluted in PBS was used as an internal control. If not indicated otherwise, cells were incubated with NVP-AUY922 for $24 \mathrm{~h}$.

\subsection{Cells and Cell Culture}

The human lung cancer cell line H1339 was cultured in RPMI 1640 medium (Thermo Fisher Scientific, Waltham, MA, USA) supplemented with 10\% v/v heat-inactivated FCS (Sigma-Aldrich, St. Louis, MO, USA), as described previously $[14,28]$. The authenticity of the tumor cell lines was tested by the DSMZ (German Collection of Microorganisms and Cell Cultures, Braunschweig, Germany). Cells were routinely checked and determined as negative for mycoplasma contaminations.

\subsection{Retroviral Vectors and Infection}

HSF-1 RNAi-Ready pSIRENRetroQ vectors with puromycin resistance were used for a specific k.d. of HSF-1. Target sequence for HSF-1 small interfering RNA was 5'-TATGGACTCCAACCTGGATAA-3' [29]. Retroviruses were produced by transfection of Phoenix cells with pSIREN-RetroQ/HSF-1 shRNA (HSF-1 k.d.) or pSIREN-RetroQ (ctrl) using Ca-phosphate. Tumor cells were infected with virus containing supernatants in the presence of $10 \mu \mathrm{g} / \mathrm{mL}$ polybrene and selected by puromycin $(2 \mu \mathrm{g} / \mathrm{mL})$. 


\subsection{Western Blot Analysis and ELISA}

Cells were lysed in TBST buffer as described previously [30]. The protein content was determined using the BCA ${ }^{\mathrm{TM}}$ Protein Assay Kit (Pierce). After transfer on PVDF membranes (BioRad) blots were blocked in $5 \%$ skim milk and incubated with antibodies $\left(4{ }^{\circ} \mathrm{C}\right.$, overnight) directed against HSF-1 (ADI-SPA-901; Enzo Life Sciences Inc., Farmingdale, NY, USA), HSF-1 phospho S326 (pHSF-1) (ab76076; abcam), Hsp70 (ADI-SPA-810; Enzo Life Sciences; cmHsp70.1; multimmune GmbH), Hsp27 (ADI-SPA-800; Enzo Life Sciences), Akt (Cell Signaling Technology Europe, Frankfurt, Germany) and $\beta$-actin (A5316; Sigma-Aldrich, St. Louis, MO, USA). Horseradish-peroxidase (HRP)-conjugated anti-rabbit/anti-mouse antibodies (Promega, Fitchburg, WI, USA, W401B/W402B) were used as secondary antibodies. Immune complexes as detected by ECL detection system (GE Healthcare, Chicago, IL, USA) were imaged digitally (ChemiDoc Touch Imaging System, Biorad, Hercules, CA, USA). Hsp70 protein concentrations in cell lysates were quantified by ELISA (R\&D systems, Minneaplis, MN, USA) following the manufacturer's recommendations.

\subsection{HSE Luciferase Assay}

The HSF-1 transcriptional activity of treated (100 nM NVP-AUY922, $24 \mathrm{~h}$ ) and untreated cells was determined using the HSE luciferase assay (Qiagen, Hilden, Germany) and the Dual Glo Luciferase assay system (Promega, Fitchburg, WI, USA) following the manufacturer's recommendations [31].

\subsection{Proliferation Assay}

Cells were seeded in 96-well plates (1000 cells/well). On the following day, cells were treated with NVP-AUY922 $(2,20,50,75,100 \mathrm{nM})$ and incubated under standard conditions for $24 \mathrm{~h}$ and $48 \mathrm{~h}$. Proliferation was measured using the colorimetric alamarBlue assay, according to manufacturer's instructions (Thermo Fisher Scientific, Waltham, MA, USA). The proliferation rate of untreated cells was defined as $100 \%$ in each experiment.

\subsection{Cell Death and Apoptosis Assays}

Cell death and apoptosis were measured by propidium iodide (PI) active Caspase-3 Apoptosis assays (BD Pharmingen) and Annexin V-FITC staining (Roche Diagnostics, Rotkreuz, Switzerland). Cells were collected $24 \mathrm{~h}$ after treatment with $100 \mathrm{nM}$ NVP-AUY922 or $24 \mathrm{~h}$ after irradiation (IR) and stained according to the manufacturer's instructions and analyzed on a FACSCalibur flow cytometer (BD, Franklin Lakes, NJ, USA).

\subsection{Clonogenic Survival Assay and Irradiation}

Radiosensitivity was determined by using a clonogenic colony formation assay as described previously [14]. Treated (NVP-AUY922, $24 \mathrm{~h}$ ) and vehicle (DMSO) treated cells were irradiated with the indicated doses using the RS225A device (Xstrahl Limited, Camberley, UK) at a dose rate of $1 \mathrm{~Gy} / \mathrm{min}$ $(70 \mathrm{keV}, 10 \mathrm{~mA}) .1 \mathrm{~h}$ after irradiation, the medium was changed by a drug-free control medium. On days 7-9 after cultivation at $37^{\circ} \mathrm{C}$ in $5 \% \mathrm{CO}_{2}$ colonies were fixed in ice-cold methanol and stained with $0.1 \%$ crystal violet. All colonies containing $\geq 50$ cells were counted automatically using an automated Bioreader ${ }^{\circledR}$ system (Bio-Sys $\mathrm{GmbH}$, Karben, Germany). Survival curves were fitted to the linear quadratic model using Sigmaplot (Systat Software Inc, Erkrath, Germany).

\subsection{Cell Cycle Analysis}

Cells were treated with NVP-AUY922 $(10 \mathrm{nM}, 24 \mathrm{~h})$ followed by irradiation with 6Gy. $24 \mathrm{~h}$ after IR cells were harvested, fixed in $70 \%$ ice-cold ethanol cells, incubated in propidium iodide (PI) staining solution (PBS, $0.1 \%$ Triton X-100, $0.2 \mathrm{mg} / \mathrm{mL}$ RNase A, $0.02 \mathrm{mg} / \mathrm{mL}$ PI) for $1 \mathrm{~h}$ at room temperature and analyzed on a FACSCalibur flow cytometer (BD). Cell cycle distribution was determined using ModFit LT (Verity Software House, Topsham, ME, USA). 


\subsection{Alkaline Comet Assay}

DNA damage was assessed by using a modified alkaline comet assay, which was originally described by Singh et al. [32,33]. The scoring of the Comet assay was performed with an epifluorescence microscope equipped with a charge-coupled device camera from Leica using the image analysis software Komet 6.0 (Andor). The results shown are derived from three independent experiments, in each experiment 100 cells were scored.

\subsection{Flow Cytometry of $\gamma H 2 A X$}

DNA double strand breaks (DBSs) were measured by using $\gamma \mathrm{H} 2 \mathrm{AX}$ (phosphorylated Histone H2AX) antibody (Alexa Fluor 488 conjugate, Novus Biologicals, Centennial, CO, USA) in control (vehicle treated) and NVP-AUY922-treated $(10 \mathrm{nM}, 24 \mathrm{~h})$ cells collected $30 \mathrm{~min}$ and $24 \mathrm{~h}$ after irradiation. The detailed protocol is described by Murakami et al. [34]. The mean fluorescence intensity (mfi) of $\gamma \mathrm{H} 2 \mathrm{AX}$-stained cells was determined by flow cytometry on a FACSCalibur instrument.

\subsection{Immunostaining for 53BP1 and Rad51 Foci}

One day after seeding, cells were treated with NVP-AUY922 $(10 \mathrm{nM}, 24 \mathrm{~h})$ followed by irradiation with the indicated doses. $4 \mathrm{~h}$ and $24 \mathrm{~h}$ after irradiation, cells were fixed in $2 \%$ paraformaldehyde/PBS. Cell lysis was achieved by submerging the slides in lysis buffer $(0.15 \%$ Triton X-100/PBS) followed by incubation in blocking buffer (1\% BSA, $0.15 \%$ glycine/PBS). Then, cells were stained with 53BP1 (1:300; Novus Biologicals, Centennial, CO, USA) and Rad51 (1:300; Merck Millipore, Burlington, MA, USA) antibodies overnight at $4{ }^{\circ} \mathrm{C}$. After washing, slides were incubated overnight with an AlexaFluor 555 secondary antibody (1:500; Thermo Fisher Scientific, Waltham, MA, USA) and, after another washing in PBS, embedded in 4',6-diamidino-2-phenylindole (DAPI)/Vectashield (Vector Laboratories, Burlingame, CA, USA) solution. The stained foci were counted in the nucleus.

\subsection{Statistics}

Statistical analysis was performed using SPSS 18.0.2 software (IBM, Armonk, NY, USA). The Student's $t$-test was used to evaluate significant differences $\left({ }^{*} p \leq 0.05,{ }^{* *} p \leq 0.01,{ }^{* * *} p \leq 0.001\right)$. All data were obtained from at least three independent experiments.

\section{Results}

\subsection{HSF-1 k.d. Reduces Hsp70/Hsp27 Expression and Sensitizes Tumor Cells towards Hsp90 Inhibition}

HSF-1 was specifically knocked down in H1339 cells by transfection with shRNA (HSF-1 k.d.). As a control, H1339 cells were transfected with an empty plasmid vector (ctrl). HSF-1 k.d. in H1339 cells was verified by a drastic reduction in the total amount of non-phosphorylated (HSF-1) and phosphorylated HSF-1 (pHSF-1) protein (Figure 1A), and a significant downregulation of the basal and NVP-AUY922-induced transcriptional activity of HSF-1, as compared to control cells (Figure 1B). The activity of NVP-AUY922 was verified by significantly upregulated intracellular Hsp70 and Hsp27 levels in control cells (Figure 1A). In HSF-1 k.d. cells the Hsp70 and Hsp27 levels increased only marginally upon NVP-AUY922 treatment (Figure 1A). Basal as well as NVP-AUY922-induced Hsp70 concentrations, as determined by ELISA, were significantly found to be reduced in HSF-1 k.d. cells compared to control cells (Figure 1C). 
A

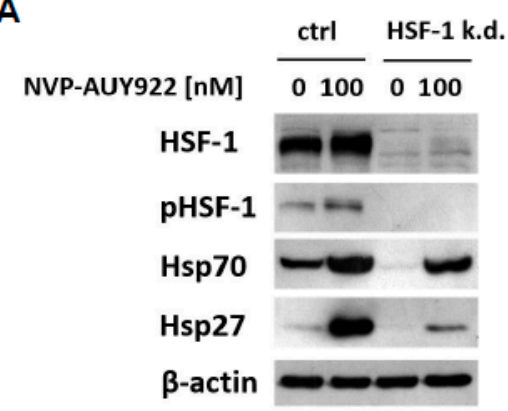

B

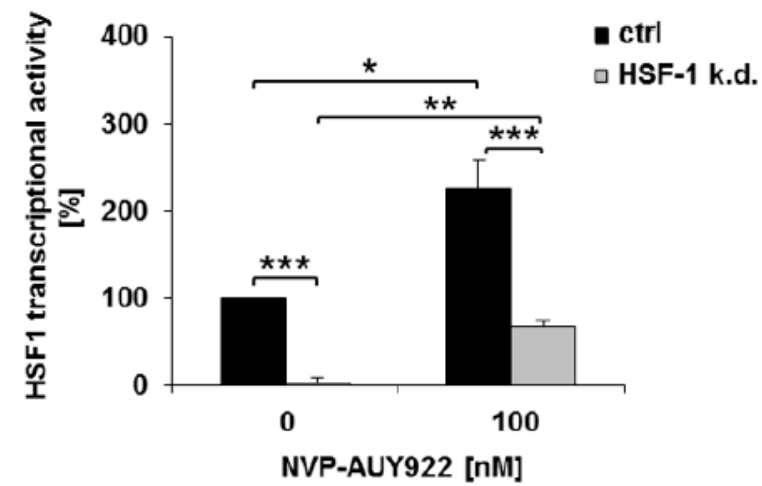

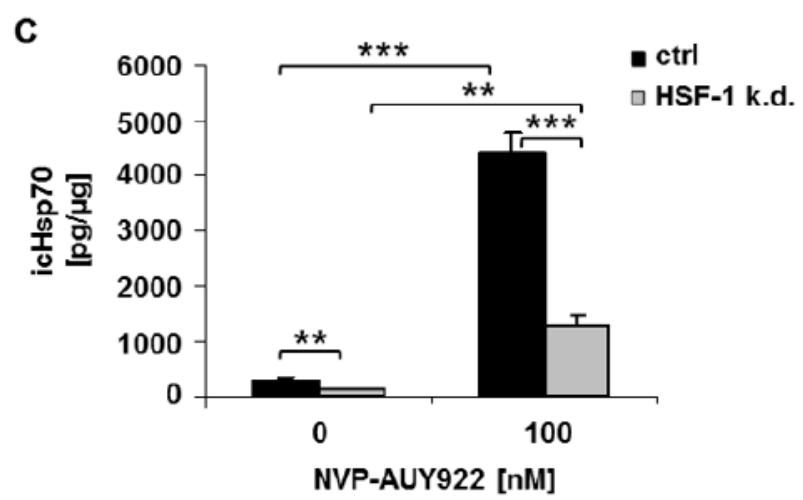

Figure 1. HSF-1 k.d. reduces the expression of Hsp70 and Hsp27 and the transcriptional activity of HSF-1. (A) Representative immunoblot showing the expression of HSF-1, HSF-1 phospho S326 (pHSF-1), Hsp70, Hsp27, and $\beta$-actin in H1339 cells transfected with control (ctrl) or HSF-1 shRNA (HSF-1 k.d.). Cells were treated with NVP-AUY922 (100 nM) for $24 \mathrm{~h}$. (B) Transcriptional activity of an HSF-1 responsive firefly luciferase construct in H1339 ctrl and HSF-1 k.d. cells. Cells were treated with NVP-AUY922 (100 nM) for $24 \mathrm{~h}$. Significance $p \leq 0.05 ;{ }^{* *} p \leq 0.01 ;{ }^{* * *} p \leq 0.001$. (C) Intracellular (ic) Hsp70 protein concentrations assessed by ELISA in H1339 ctrl and HSF-1 k.d. cells treated with NVP-AUY922 (100 nM) for $24 \mathrm{~h}$. Significance ${ }^{*} p \leq 0.05 ;{ }^{* *} p \leq 0.01 ;{ }^{* * *} p \leq 0.001$.

Targeting HSF-1 combined with inhibition of Hsp90 resulted in a concentration-dependent, significant reduction in proliferation of H1339 HSF-1 k.d. cells $24 \mathrm{~h}$ (Figure 2A) and $48 \mathrm{~h}$ (Figure 2B) after treatment. Cell death (Figure 2C) and apoptosis, as determined by Annexin V (Figure 2D) and active caspase 3 (Figure 2E) assays, was significantly increased in H1339 HSF-1 k.d. cells compared to H1339 control cells after treatment with NVP-AUY922 (100 nM). 


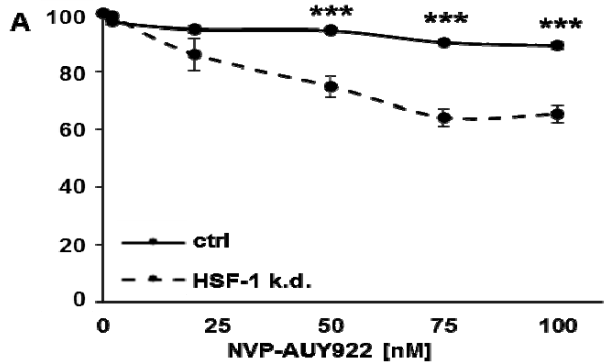

c

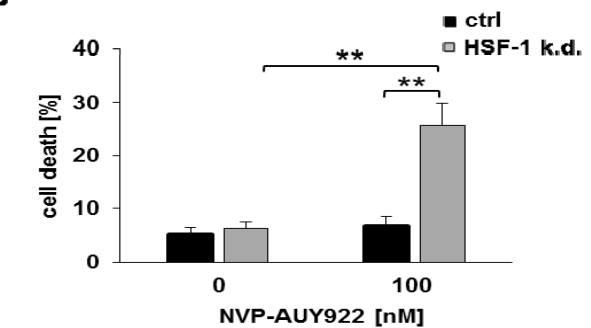

D

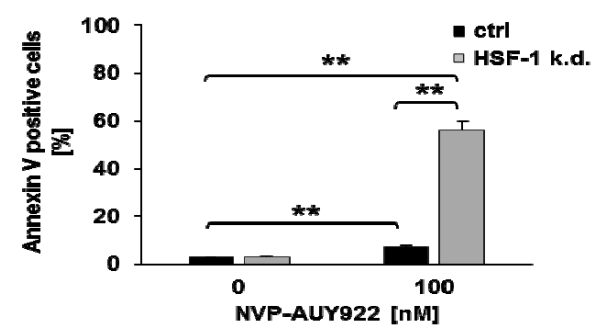

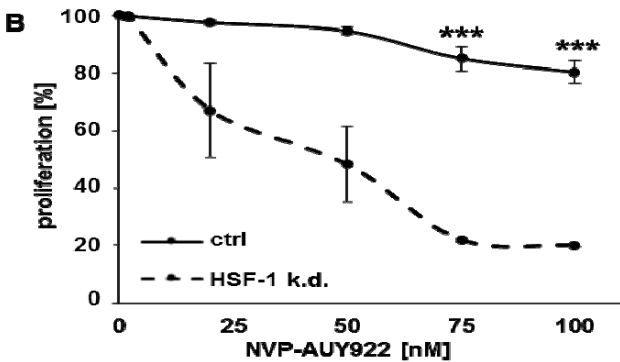

E

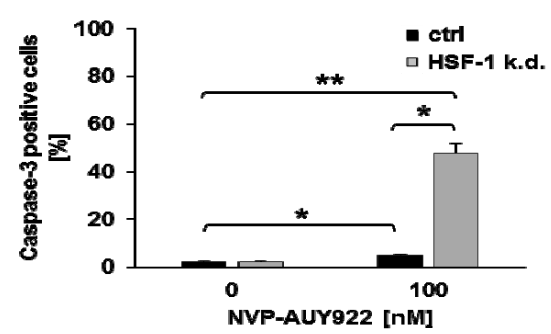

Figure 2. Hsp90 inhibition significantly inhibits proliferation and induces apoptosis in HSF-1 k.d. cells. Proliferation assay of H1339 ctrl and HSF-1 k.d. cells treated with NVP-AUY922 (0, 20, 50, 75, $100 \mathrm{nM})$ for $24 \mathrm{~h}(\mathbf{A})$ and $48 \mathrm{~h}(\mathbf{B})$. Significance ${ }^{* * *} p \leq 0.001$. (C) Measurement of cell death by propidium iodide (PI) staining in H1339 ctrl and HSF-1 k.d. cells treated with NVP-AUY922 (100 nM) for $24 \mathrm{~h}$. Significance ${ }^{* *} p \leq 0.01$. Measurement of apoptosis induction by Annexin V (D) and active Caspase-3 (E) staining in untreated (0 nM) and NVP-AUY922 (100 nM) treated H1339 ctrl and HSF-1 k.d. cells after 24 h. Significance $* \leq 0.05 ;{ }^{* *} p \leq 0.01$.

\subsection{Low Hsp90 Inhibitor Concentrations Potentiate Radiosensitivity of HSF-1 k.d. Tumor Cells}

HSF-1 k.d. alone does not radiosensitize H1339 cells, as determined by clonogenic cell survival and $\mathrm{D}_{50}$ values (Figure 3A, Supplementary Table S1A) [34]. Therefore, we studied the combined effects of an HSF-1 k.d. and low concentrations of the Hsp90 inhibitor NVP-AUY922 (1, 2, and 5 nM). No radiosensitization was achieved in control cells by low NVP-AUY922 concentrations (up to 2 nM), whereas HSF-1 k.d. cells could be significantly radiosensitized by 2 nM NVP-AUY922 (Figure 3B, Supplementary Table S1B). A concentration of $5 \mathrm{nM}$ NVP-AUY922 increased the radiosensitivity in both cell types, but the radiosensitizing effect was significantly more pronounced in HSF-1 k.d. cells. The activity of NVP-AUY922 at low concentrations $(0,2,5 \mathrm{nM})$ was demonstrated by a downregulated expression of Akt, a client protein of Hsp90. 
A

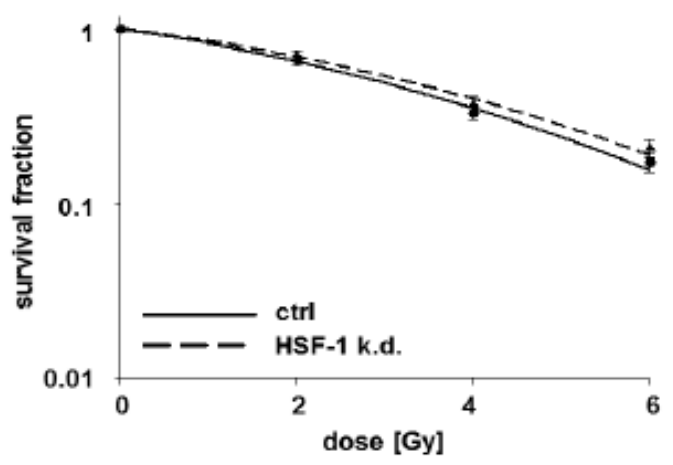

B

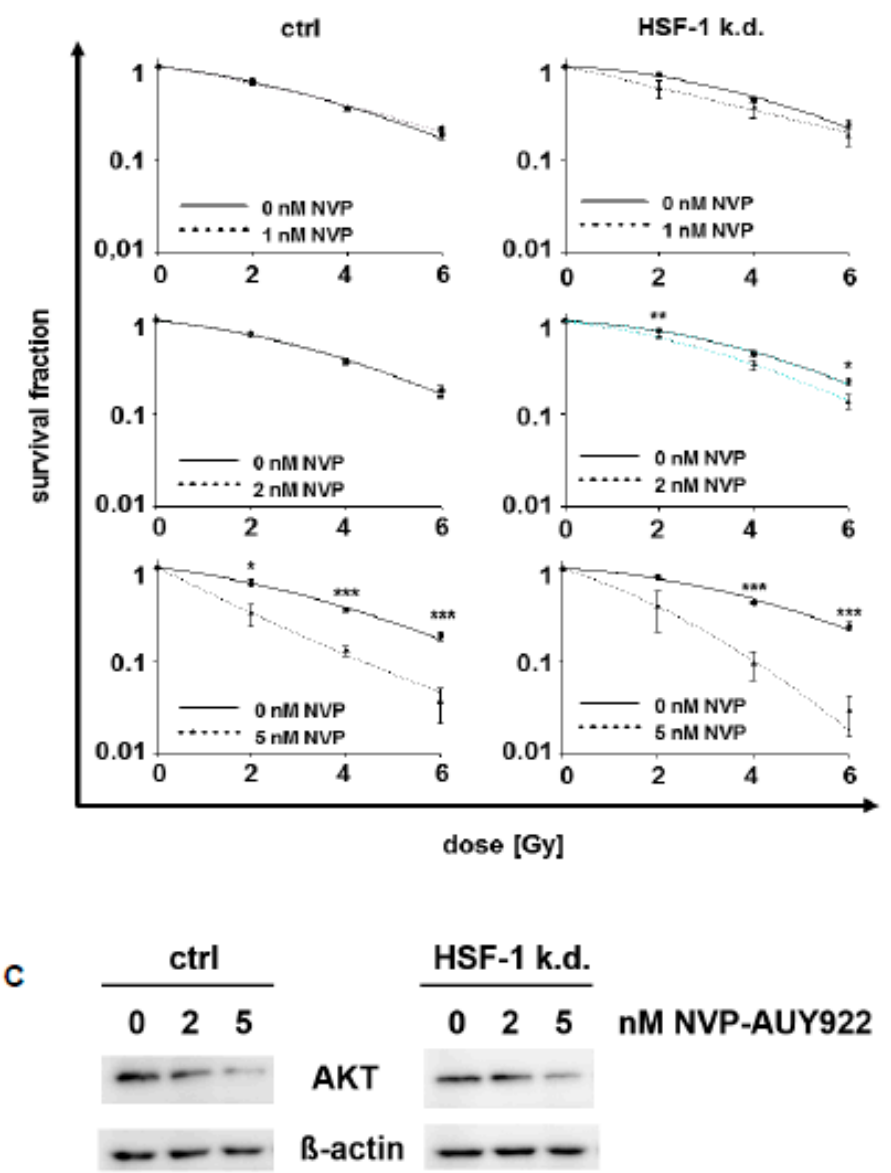

Figure 3. Hsp90 inhibition at low doses combined with irradiation significantly increases radiosensitivity in HSF-1 k.d. cells. (A) Colony forming assay of H1339 ctrl and HSF-1 k.d. cells after irradiation with 0, 2, 4, and 6Gy. (B) Colony forming assay of H1339 ctrl and HSF-1 k.d. cells after treatment with low concentrations of NVP-AUY922 (0, 1, 2, $5 \mathrm{nM})$ for $24 \mathrm{~h}$ and irradiation with $0,2,4$, and 6Gy. Significance ${ }^{*} p \leq 0.05 ;{ }^{* *} p \leq 0.01 ;{ }^{* * *} p \leq 0.001$. (C) Representative immunoblot showing the expression of Akt and $\beta$-actin in H1339 cells transfected with control (ctrl) or HSF-1 shRNA (HSF-1 k.d.). Cells were treated with low concentrations of NVP-AUY922 $(0,2,5 \mathrm{nM})$ for $24 \mathrm{~h}$.

\subsection{Hsp90 Inhibition and Irradiation Increase DNA Damage Response in HSF-1 k.d. Tumor Cells}

To identify the mechanisms underlying the radiosensitizing effect of a combined Hsp90 and HSF-1 inhibition in lung cancer cells, cell cycle phase distribution, apoptosis, and DNA damage response were analyzed. Neither the radiation-induced G2/M arrest (Figure S1) nor radiation-induced apoptosis (Supplementary Figure S2) were significantly impaired by NVP-AUY922 in H1339 control and HSF-1 k.d. cells. However, the DNA damage response, as determined by an alkaline comet assay, clearly 
demonstrated a significantly increased DNA content in the comet tail $24 \mathrm{~h}$ after the combined treatment with NVP-AUY922 (10 nM) and irradiation (6Gy) in HSF-1 k.d. cells (Figure 4A,B).

A

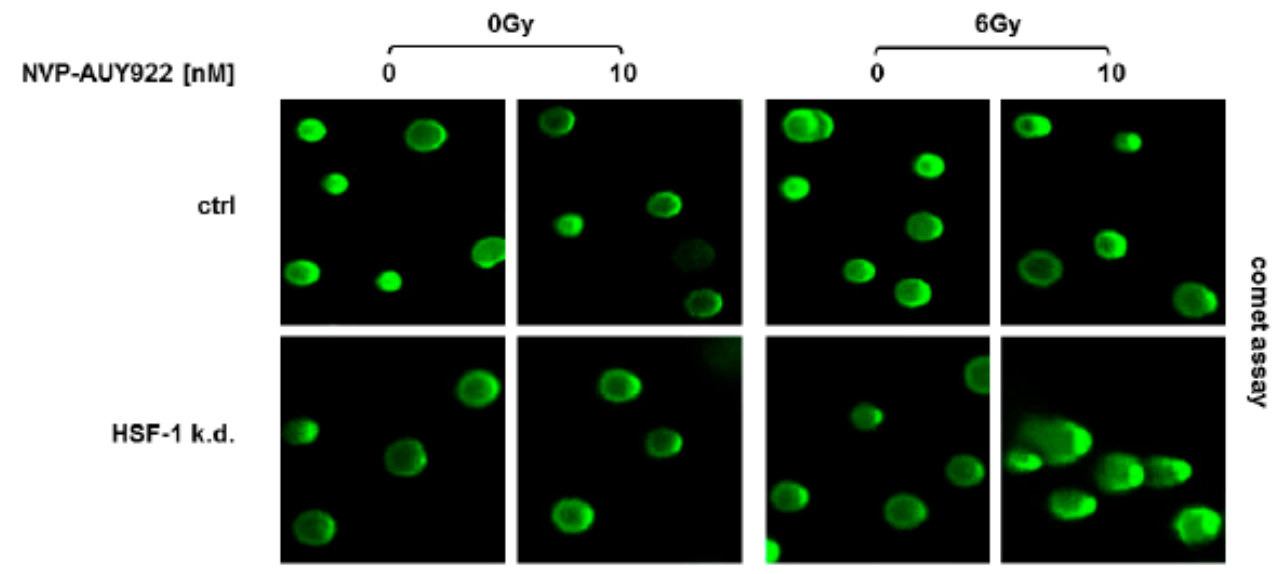

B

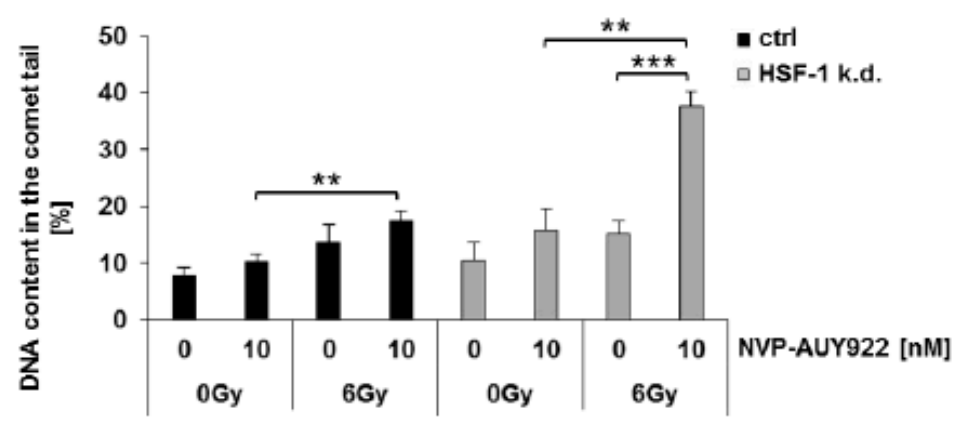

Figure 4. Hsp90 inhibition combined with irradiation significantly increases DNA damage in HSF-1 k.d. cells. (A) Comet assay $24 \mathrm{~h}$ after irradiation. Representative images of H1339 ctrl and HSF-1 k.d. cells after treatment with NVP-AUY922 (10 nM) for $24 \mathrm{~h}$ and irradiation with 0Gy and 6Gy.

(B) Quantification of the results of the comet assay shown in (A). Significance ${ }^{* *} p \leq 0.01$; ${ }^{* * *} p \leq 0.001$.

3.4. Hsp90 Inhibition Delays the Radiation-Induced DNA Double Strand Break (DSB) Repair in HSF-1 k.d. Cells

DNA double strand breaks (DSBs) were determined in sham treated (0Gy) and irradiated (6Gy) H1339 ctrl and HSF-1 k.d. cells by measuring the expression of the DSB repair enzyme $\gamma \mathrm{H} 2 \mathrm{AX}$. In line with the results of the comet assay, a combined treatment of irradiation (6Gy) and NVP-AUY922 $(10 \mathrm{nM})$ led to a significant increase in the expression density of $\gamma \mathrm{H} 2 \mathrm{AX}$ in HSF-1 k.d. cells but not in control cells (Figure 5A).

These results were confirmed by a 53BP1 foci assay. Since uncountable 53BP1 foci were produced by 6Gy (data not shown), the cells were irradiated only with 2 and 4Gy which caused a mean number of 1.8 and 3 repair foci per nucleus, in H1339 control and HSF-1 k.d. cells, respectively (Figure 5B). In HSF-1 k.d. cells the number of repair foci increased significantly up to 4.8 after a combined treatment with NVP-AUY922 (10 nM) and irradiation (4Gy), compared to irradiation alone (Figure 5B). These data suggest that a combined treatment significantly augments the number of DSBs in HSF-1 k.d. cells after irradiation. Since this effect was not observed $30 \mathrm{~min}$ after irradiation (data not shown), we hypothesize that the late DNA DSB repair might be impaired in HSF-1 k.d. cells. 

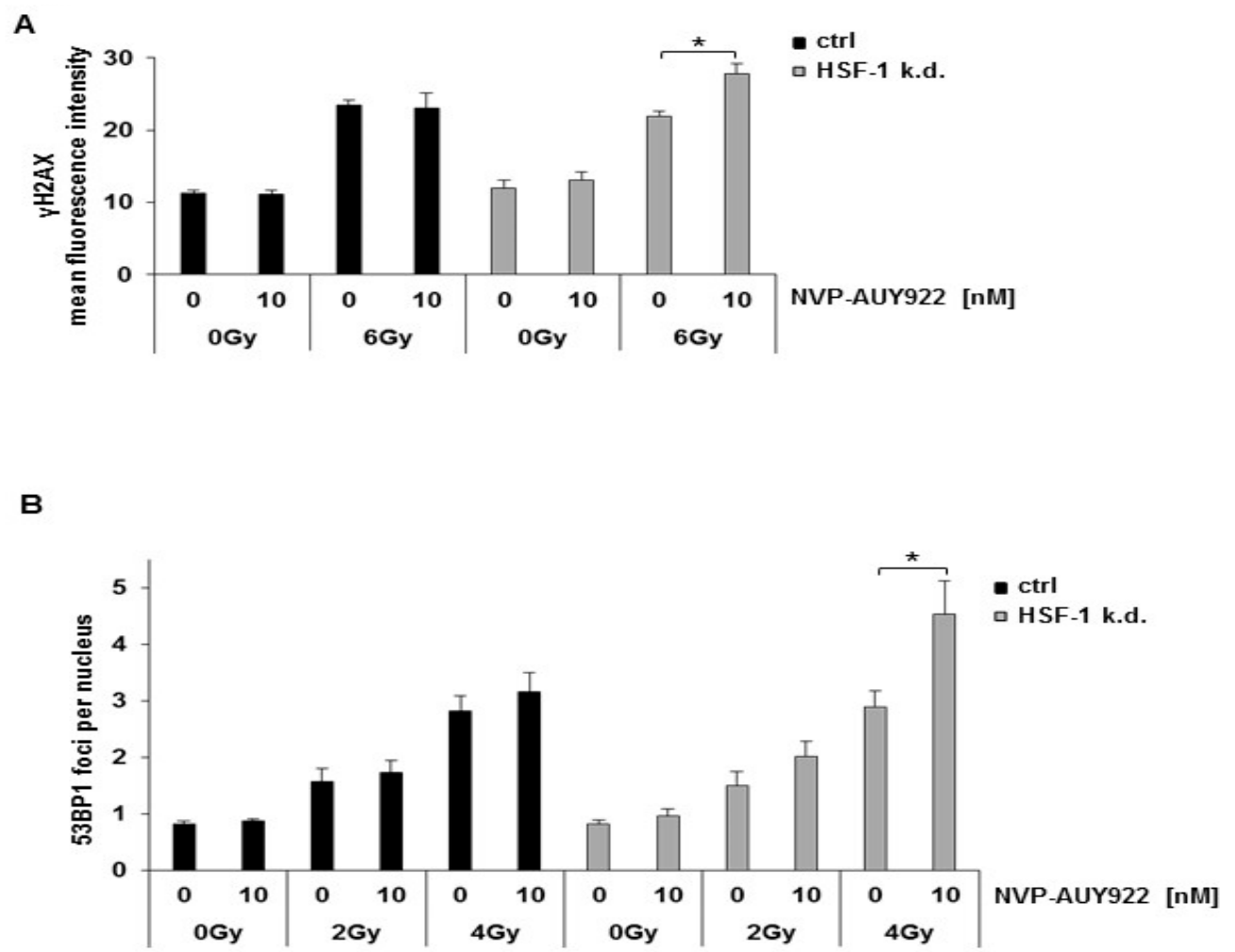

Figure 5. Hsp90 inhibition combined with irradiation significantly increases DNA double strand breaks in HSF-1 k.d. cells. (A) Mean fluorescence intensity of $\gamma \mathrm{H} 2 \mathrm{AX}$ measured by flow cytometry $24 \mathrm{~h}$ after irradiation. H1339 ctrl and HSF-1 k.d. cells after treatment with NVP-AUY922 (10 nM) for $24 \mathrm{~h}$ and irradiation with 0Gy and 6Gy. Significance * $p \leq 0.05$. (B) Quantification of 53BP1 foci in H1339 ctrl and HSF-1 k.d. cells $24 \mathrm{~h}$ after irradiation. Cells were treated with NVP-AUY922 (10 nM) for $24 \mathrm{~h}$ following irradiation with 0Gy, 2Gy, and 4Gy. Significance * $p \leq 0.05$.

3.5. Hsp90 Inhibition Impairs Rad51-Mediated Homologous Recombination in Irradiated HSF-1 k.d. Cells

In eukaryotic cells, a major pathway involved in DSB repair is the homologous recombination (HR) [35-37]. To investigate whether NVP-AUY922 affects HR in HSF-1 k.d. cells, the formation of Rad51 foci was determined after the combined treatment regimen.

Similar to U-2 OS (osteosarcoma), A-431 (epidermoid carcinoma), and U-251 MG (glioblastoma) cells [38] Rad51 mainly resides in the nucleoli also in untreated H1339 control cells. As expected, irradiation induces an increase in Rad51 foci in control and HSF-1 k.d. cells that was slightly more pronounced in the HSF-1 k.d. cells. Representative images of a single microscopic layer are illustrated in Figure 6A. Hsp90 inhibition with NVP-AUY922 (10 nM) resulted in a significantly stronger reduction in the number of Rad51 foci in HSF-1 k.d. cells compared to control cells (Figure 6B). 
A NVP-AUY922 [nM]

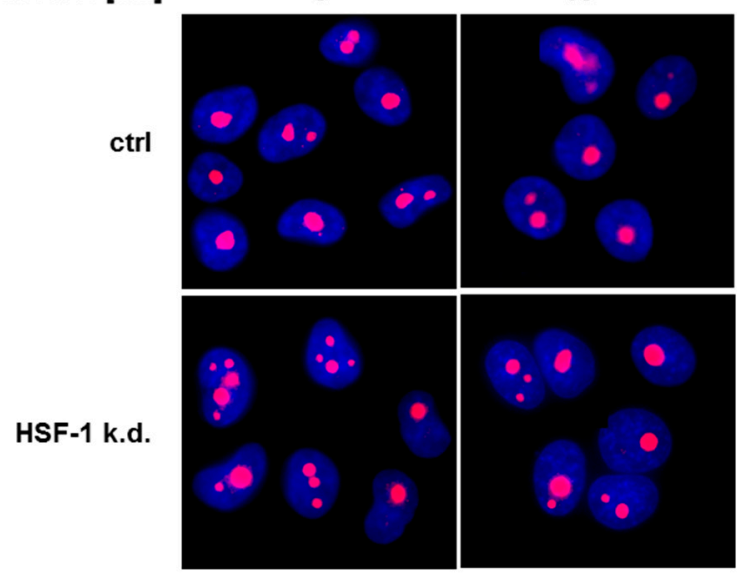

B

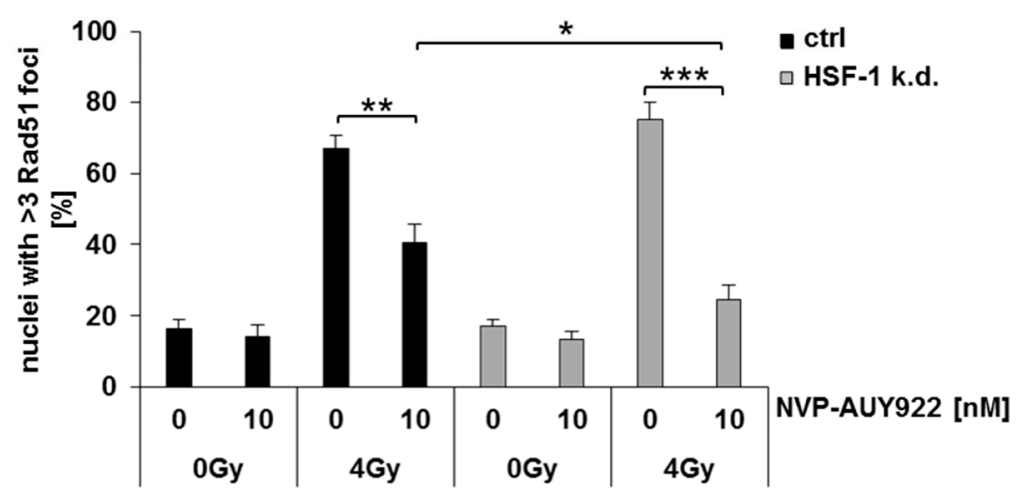

Figure 6. Combined treatment of Hsp90 inhibition and irradiation significantly impairs homologous recombination in HSF-1 k.d. cells. (A) Representative images of Rad51 foci in H1339 ctrl and HSF-1 k.d. cells $4 \mathrm{~h}$ after irradiation. H1339 ctrl and HSF-1 k.d. cells after treatment with NVP-AUY922 (10 nM) for $24 \mathrm{~h}$ and irradiation with 0Gy and 4Gy. (B) Quantification of Rad51 foci $4 \mathrm{~h}$ after irradiation. H1339 ctrl and HSF-1 k.d. cells were treated with NVP-AUY922 $(10 \mathrm{nM})$ for $24 \mathrm{~h}$ following irradiation with 0 Gy and 4Gy. Significance ${ }^{*} p \leq 0.05 ;{ }^{* *} p \leq 0.01 ;{ }^{* * *} p \leq 0.001$.

\section{Discussion}

HSF-1 is a ubiquitously expressed transcription factor that plays a central role in tumor biology (e.g., malignant transformation, carcinogenesis, and metastasis) [39-42]. HSF-1 activates the heat shock response in normal and tumor cells following stress, and thereby induces the synthesis of Hsp70 and Hsp27 [19-21]. Compared to normal cells, most human tumor cells exhibit an upregulated expression of HSF-1 and HSPs already under physiological conditions due to an overexpression of oncogenic proteins that require HSPs for its proper folding. Therefore, elevated HSP levels contribute to a malignant tumor phenotype and mediate resistance to chemo- and radiotherapy $[6,8]$.

The inhibition of Hsp90 is considered as a promising approach to improve radiosensitivity since Hsp90 inhibition can impair a multiplicity of different oncogenic pathways in a variety of human tumor entities [43-50]. Many studies have shown that inhibition of Hsp90 induces proteasomal degradation of many important oncogenic client proteins [11-13,51,52].

The firstly described Hsp90 inhibitor geldanamycin and its chemical derivates 17-AAG and 17-DMAG have demonstrated radiosensitizing effects, in vitro [43,44,46,48,53-55]; however, poor water-solubility and severe hepatotoxicity limited their clinical applications [51,56-58]. The small 
synthetic Hsp90 inhibitor NVP-AUY922 is less toxic, shows an improved biodistribution and promising anti-tumor activity, in vitro [51,59].

Despite these advantages, similar to other clinically applied Hsp90 inhibitors, also NVP-AUY922 causes the release of HSF-1 from the Hsp90 complex and as a result HSF-1 gets activated and induces the transcription of Hsp70 and Hsp27 [23,24]. Hsp70 and Hsp27 exert cytoprotective activities and thereby can counteract the anti-tumor effects of the Hsp90 inhibition.

Previously, it was reported that NZ28 - an inhibitor of several transcription factors including HSF-1, SP1, and NF-kB - can increase the radiosensitivity in human lung cancer cells. In combination with the Hsp90 inhibitor NVP-AUY922, the concentration of NZ28 could be significantly reduced to achieve radiosensitization $[31,60]$. With respect to these findings, we investigated the radiosensitizing effects of an HSF-1 k.d. in combination with low concentrations of NVP-AUY922 in lung cancer cells.

In line with our previous findings, the k.d. of HSF-1 alone does not affect the radiosensitivity of H1339 cells [34]. However, in combination with the Hsp90 inhibitor NVP-AUY922, the radiosensitivity of $\mathrm{H} 1339$ tumor cells was significantly increased due to a down-regulation of basal and NVP-AUY922-induced levels of Hsp70 and Hsp27. These data are consistent with published data [61] demonstrating that HSF-1 depletion by shRNA can sensitize tumor cells towards high concentrations of Hsp90 inhibitors.

Our study showed for the first time, that the amount of the Hsp90 inhibitor NVP-AUY922 could be drastically reduced to the low nanomolar range when applied in combination with an HSF-1 k.d. to induce a significant radiosensitization. Since the application of Hsp90 inhibitors in the clinics is often hampered by their hepatotoxicity this finding is key for clinical applications. Our results are in line with an excellent study provided by Kudryavtsev et al. who demonstrated that a combination of Hsp90 inhibition with inhibitors of the Hsp70 response can increase radiation-induced cell death and thereby decrease post-radiation viability and clonogenicity in highly radioresistant, proliferating tumor cells. Furthermore, this group could show similar effects in proliferating tumor endothelial cells, which in turn can cause a suppression of tumor angiogenesis. In accordance to our data derived by an HSF-1 k.d., similar mechanisms of radiosensitization-including apoptosis induction and incomplete repair of DNA double strand breaks-have been demonstrated for inhibitors of the Hsp70 induction such as quercetin, triptolide, KNK437, and NZ28 [62].

Stingl et al. [16] indicated that NVP-AUY922 affects apoptosis as well as cell cycle-phase distribution and thereby induces radiosensitization. In line with these findings, Niewidok et al. [15] and Gandhi et al. [63] have shown that the depletion of pro-apoptotic proteins resulted in NVP-AUY922-mediated radiosensitization in lung carcinoma cells in vitro.

In our study, low concentrations of NVP-AUY922 combined with radiation did neither impact cell cycle distribution nor apoptosis in control and HSF-1 k.d. tumor cell lines (Supplementary data). Nevertheless, low Hsp90 inhibitor concentrations potentiate radiosensitization that is most likely due to an increase in DNA double-strand breaks of HSF-1 k.d. cells. In line with others showing an impairment of HR after irradiation and treatment with Hsp90 inhibitors [18,64], we also could demonstrate a significant reduction in Rad51 foci in irradiated HSF-1 k.d. cells after incubation with NVP-AUY922.

With respect to future clinical applications of a combined HSF-1 and Hsp90 inhibition to overcome radioresistance of tumor cells, presently different HSF-1 inhibiting substances such as quercetin [65], KNK437 [66], triptolide [67], NZ28 [29,31], N-amino-ethylamino derivative of colchicine (AEAC) [68], and cardenolide [69] are under investigations. However, effective concentrations in the micromolar range of quercetin, KNK437 and NZ28 are expected to exert adverse effects in patients. In contrast, triptolide and AEAC have been found to be effective in the low nanomolar range. Toxicity studies are on the way to evaluate normal tissue toxicities of these anti-Hsp70 drugs. 


\section{Conclusions}

In summary, our results indicate that a combined treatment consisting of HSF-1 k.d. and low concentrations of the Hsp90 inhibitor NVP-AUY922 can significantly increase radiosensitivity in lung cancer cells. In the future, a dual targeting of HSF-1 and Hsp90 might provide a promising approach to increase the effectiveness of radiotherapy with less side effects by reducing the concentration of hepatotoxic Hsp90 inhibitors in the treatment of cancer patients.

Supplementary Materials: The following are available online at http://www.mdpi.com/2073-4409/8/10/1166/s1, Figure S1: HSF-1 knockdown cells show no difference in cell cycle distribution after combined Hsp90 inhibition and irradiation, Figure S2: HSF-1 knockdown and control cells show no difference in apoptosis induction after combined Hsp90 inhibition and irradiation, Table S1: Summary of radiobiological parameters.

Author Contributions: Conceptualization: D.S., A.K., and G.M.; Investigation: A.K. and M.S.; Resources: S.E.C.; Formal analysis: B.H.; Writing-Original Draft Preparation: A.K.; Writing-Review and Editing: D.S. and G.M.; Supervision: D.S. and G.M.; Funding Acquisition, A.K., D.S., and G.M.

Funding: This work was supported by the Wilhelm Sander-Stiftung (2012.078.1), Deutsche Forschungsgemeinschaft DFG (KU3500/2-1, SFB824/3, INST95/980-1FUGG) and the Technische Universität München within the funding program Open Access Publishing, Bundesministerium für Bildung und Forschung BMBF (02NUK038A, 01GU0823), Klinikum rechts der Isar (KKF:15-06) and DKTK-ROG.

Acknowledgments: The authors want to thank Julia Yaglom and Michael Sherman (Boston University School of Medicine, USA) for providing the retroviral vectors pSIREN-RetroQ/HSF-1 shRNA and pSIREN-RetroQ and Thorsten Buch for the help with plasmid reproduction and purification.

Conflicts of Interest: Stephanie E. Combs reports personal fees and non-financial support from BMS, personal fees and non-financial support from Brainlab and non-financial support from Daiichi Sankyo outside the submitted work.

\section{References}

1. Torre, L.A.; Bray, F.; Siegel, R.L.; Ferlay, J.; Lortet-Tieulent, J.; Jemal, A. Global cancer statistics, 2012. CA: Cancer J. Clin. 2015, 65, 87-108. [CrossRef] [PubMed]

2. Wood, S.L.; Pernemalm, M.; Crosbie, P.A.; Whetton, A.D. Molecular histology of lung cancer: From targets to treatments. Cancer Treat. Rev. 2015, 41, 361-375. [CrossRef] [PubMed]

3. Park, M.R.; Park, Y.H.; Choi, J.W.; Park, D.I.; Chung, C.U.; Moon, J.Y.; Park, H.S.; Jung, S.S.; Kim, J.O.; Kim, S.Y.; et al. Progression-free survival: An important prognostic marker for long-term survival of small cell lung cancer. Tuberc. Respir. Dis. 2014, 76, 218-225. [CrossRef] [PubMed]

4. Novello, S.; Vavala, T.; Levra, M.G.; Solitro, F.; Pelosi, E.; Veltri, A.; Scagliotti, G.V. Early response to chemotherapy in patients with non-small-cell lung cancer assessed by [18F]-fluoro-deoxy-D-glucose positron emission tomography and computed tomography. Clin. Lung Cancer 2013, 14, 230-237. [CrossRef] [PubMed]

5. Moulick, K.; Ahn, J.H.; Zong, H.; Rodina, A.; Cerchietti, L.; Gomes DaGama, E.M.; Caldas-Lopes, E.; Beebe, K.; Perna, F.; Hatzi, K.; et al. Affinity-based proteomics reveal cancer-specific networks coordinated by Hsp90. Nat. Chem. Biol. 2011, 7, 818-826. [CrossRef] [PubMed]

6. Soo, E.T.; Yip, G.W.; Lwin, Z.M.; Kumar, S.D.; Bay, B.H. Heat shock proteins as novel therapeutic targets in cancer. In Vivo 2008, 22, 311-315. [PubMed]

7. Bonay, M.; Soler, P.; Riquet, M.; Battesti, J.P.; Hance, A.J.; Tazi, A. Expression of heat shock proteins in human lung and lung cancers. Am. J. Respir. Cell Mol. Biol. 1994, 10, 453-461. [CrossRef]

8. Ciocca, D.R.; Calderwood, S.K. Heat shock proteins in cancer: Diagnostic, prognostic, predictive, and treatment implications. Cell Stress Chaperones 2005, 10, 86-103. [CrossRef]

9. Garrido, C.; Brunet, M.; Didelot, C.; Zermati, Y.; Schmitt, E.; Kroemer, G. Heat shock proteins 27 and 70 : Anti-apoptotic proteins with tumorigenic properties. Cell Cycle 2006, 5, 2592-2601. [CrossRef]

10. Pearl, L.H.; Prodromou, C. Structure and mechanism of the Hsp90 molecular chaperone machinery. Annu. Rev. Biochem. 2006, 75, 271-294. [CrossRef]

11. Whitesell, L.; Lindquist, S.L. HSP90 and the chaperoning of cancer. Nat. Rev. Cancer 2005, 5, 761-772. [CrossRef] [PubMed]

12. Kabakov, A.E.; Kudryavtsev, V.A.; Gabai, V.L. Hsp90 inhibitors as promising agents for radiotherapy. J. Mol. Med. 2010, 88, 241-247. [CrossRef] [PubMed] 
13. Kaplan, K.B.; Li, R. A prescription for 'stress'-the role of Hsp90 in genome stability and cellular adaptation. Trends Cell Biol. 2012, 22, 576-583. [CrossRef] [PubMed]

14. Schilling, D.; Bayer, C.; Li, W.; Molls, M.; Vaupel, P.; Multhoff, G. Radiosensitization of normoxic and hypoxic h1339 lung tumor cells by heat shock protein 90 inhibition is independent of hypoxia inducible factor-1alpha. PLOS ONE 2012, 7, e31110. [CrossRef] [PubMed]

15. Niewidok, N.; Wack, L.J.; Schiessl, S.; Stingl, L.; Katzer, A.; Polat, B.; Sukhorukov, V.L.; Flentje, M.; Djuzenova, C.S. Hsp90 Inhibitors NVP-AUY922 and NVP-BEP800 May Exert a Significant Radiosensitization on Tumor Cells along with a Cell Type-Specific Cytotoxicity. Transl. Oncol. 2012, 5, 356-369. [CrossRef] [PubMed]

16. Stingl, L.; Stuhmer, T.; Chatterjee, M.; Jensen, M.R.; Flentje, M.; Djuzenova, C.S. Novel HSP90 inhibitors, NVP-AUY922 and NVP-BEP800, radiosensitise tumour cells through cell-cycle impairment, increased DNA damage and repair protraction. Br. J. Cancer 2010, 102, 1578-1591. [CrossRef]

17. Hashida, S.; Yamamoto, H.; Shien, K.; Ohtsuka, T.; Suzawa, K.; Maki, Y.; Furukawa, M.; Soh, J.; Asano, H.; Tsukuda, K.; et al. Hsp90 inhibitor NVP-AUY922 enhances the radiation sensitivity of lung cancer cell lines with acquired resistance to EGFR-tyrosine kinase inhibitors. Oncol. Rep. 2015, 33, 1499-1504. [CrossRef]

18. Zaidi, S.; McLaughlin, M.; Bhide, S.A.; Eccles, S.A.; Workman, P.; Nutting, C.M.; Huddart, R.A.; Harrington, K.J. The HSP90 inhibitor NVP-AUY922 radiosensitizes by abrogation of homologous recombination resulting in mitotic entry with unresolved DNA damage. PLoS ONE 2012, 7, e35436. [CrossRef]

19. Sorger, P.K.; Pelham, H.R. Yeast heat shock factor is an essential DNA-binding protein that exhibits temperature-dependent phosphorylation. Cell 1988, 54, 855-864. [CrossRef]

20. McMillan, D.R.; Xiao, X.; Shao, L.; Graves, K.; Benjamin, I.J. Targeted disruption of heat shock transcription factor 1 abolishes thermotolerance and protection against heat-inducible apoptosis. J. Biol. Chem. 1998, 273, 7523-7528. [CrossRef]

21. Xie, Y.; Zhong, R.; Chen, C.; Calderwood, S.K. Heat shock factor 1 contains two functional domains that mediate transcriptional repression of the c-fos and c-fms genes. J. Biol. Chem. 2003, 278, 4687-4698. [CrossRef] [PubMed]

22. Powers, M.V.; Workman, P. Targeting of multiple signalling pathways by heat shock protein 90 molecular chaperone inhibitors. Endocr. -Relat. Cancer 2006, 13 (Suppl. 1), S125-S135. [CrossRef] [PubMed]

23. Zou, J.; Guo, Y.; Guettouche, T.; Smith, D.F.; Voellmy, R. Repression of heat shock transcription factor HSF1 activation by HSP90 (HSP90 complex) that forms a stress-sensitive complex with HSF1. Cell 1998, 94, 471-480. [CrossRef]

24. Mendillo, M.L.; Santagata, S.; Koeva, M.; Bell, G.W.; Hu, R.; Tamimi, R.M.; Fraenkel, E.; Ince, T.A.; Whitesell, L.; Lindquist, S. HSF1 drives a transcriptional program distinct from heat shock to support highly malignant human cancers. Cell 2012, 150, 549-562. [CrossRef] [PubMed]

25. Trepel, J.; Mollapour, M.; Giaccone, G.; Neckers, L. Targeting the dynamic HSP90 complex in cancer. Nat. Rev. Cancer 2010, 10, 537-549. [CrossRef]

26. Guttmann, D.M.; Koumenis, C. The heat shock proteins as targets for radiosensitization and chemosensitization in cancer. Cancer Biol. Ther. 2011, 12, 1023-1031. [CrossRef] [PubMed]

27. Guttmann, D.M.; Hart, L.; Du, K.; Seletsky, A.; Koumenis, C. Inhibition of Hsp27 radiosensitizes head-and-neck cancer by modulating deoxyribonucleic acid repair. Int. J. Radiat. Oncol. Biol. Phys. 2013, 87, 168-175. [CrossRef]

28. Wiskirchen, J.; Groenewaeller, E.F.; Kehlbach, R.; Heinzelmann, F.; Wittau, M.; Rodemann, H.P.; Claussen, C.D.; Duda, S.H. Long-term effects of repetitive exposure to a static magnetic field (1.5 T) on proliferation of human fetal lung fibroblasts. Magn. Reson. Med. 1999, 41, 464-468. [CrossRef]

29. Zaarur, N.; Gabai, V.L.; Porco, J.A., Jr.; Calderwood, S.; Sherman, M.Y. Targeting heat shock response to sensitize cancer cells to proteasome and Hsp90 inhibitors. Cancer Res. 2006, 66, 1783-1791. [CrossRef]

30. Schilling, D.; Bayer, C.; Geurts-Moespot, A.; Sweep, F.C.; Pruschy, M.; Mengele, K.; Sprague, L.D.; Molls, M. Induction of plasminogen activator inhibitor type-1 (PAI-1) by hypoxia and irradiation in human head and neck carcinoma cell lines. BMC Cancer 2007, 7, 143. [CrossRef]

31. Schilling, D.; Kühnel, A.; Konrad, S.; Tetzlaff, F.; Bayer, C.; Yaglom, J.; Multhoff, G. Sensitizing tumor cells to radiation by targeting the heat shock response. Cancer Lett. 2015, 360, 294-301. [CrossRef]

32. Singh, N.P.; McCoy, M.T.; Tice, R.R.; Schneider, E.L. A simple technique for quantitation of low levels of DNA damage in individual cells. Exp. Cell Res. 1988, 175, 184-191. [CrossRef] 
33. Sipinen, V.; Laubenthal, J.; Baumgartner, A.; Cemeli, E.; Linschooten, J.O.; Godschalk, R.W.; Van Schooten, F.J.; Anderson, D.; Brunborg, G. In vitro evaluation of baseline and induced DNA damage in human sperm exposed to benzo[a]pyrene or its metabolite benzo[a]pyrene-7,8-diol-9,10-epoxide, using the comet assay. Mutagenesis 2010, 25, 417-425. [CrossRef] [PubMed]

34. Murakami, N.; Kühnel, A.; Schmid, T.E.; Ilicic, K.; Stangl, S.; Braun, I.S.; Gehrmann, M.; Molls, M.; Itami, J.; Multhoff, G. Role of membrane Hsp70 in radiation sensitivity of tumor cells. Radiat. Oncol. 2015, 10, 149. [CrossRef]

35. Ciccia, A.; Elledge, S.J. The DNA damage response: Making it safe to play with knives. Mol. Cell 2010, 40, 179-204. [CrossRef] [PubMed]

36. Hiom, K. Coping with DNA double strand breaks. DNA Repair 2010, 9, 1256-1263. [CrossRef] [PubMed]

37. Pardo, B.; Gomez-Gonzalez, B.; Aguilera, A. DNA repair in mammalian cells: DNA double-strand break repair: How to fix a broken relationship. Cell. Mol. Life Sci. 2009, 66, 1039-1056. [CrossRef]

38. Uhlen, M.; Fagerberg, L.; Hallstrom, B.M.; Lindskog, C.; Oksvold, P.; Mardinoglu, A.; Sivertsson, A.; Kampf, C.; Sjostedt, E.; Asplund, A.; et al. Proteomics. Tissue-based map of the human proteome. Science 2015, 347, 1260419. [CrossRef]

39. Sakurai, H.; Enoki, Y. Novel aspects of heat shock factors: DNA recognition, chromatin modulation and gene expression. FEBS J. 2010, 277, 4140-4149. [CrossRef]

40. Dai, C.; Whitesell, L.; Rogers, A.B.; Lindquist, S. Heat shock factor 1 is a powerful multifaceted modifier of carcinogenesis. Cell 2007, 130, 1005-1018. [CrossRef]

41. Jin, X.; Eroglu, B.; Moskophidis, D.; Mivechi, N.F. Targeted deletion of Hsf1, 2, and 4 genes in mice. Methods Mol. Biol. 2011, 787, 1-20. [CrossRef] [PubMed]

42. Zhao, Y.H.; Zhou, M.; Liu, H.; Ding, Y.; Khong, H.T.; Yu, D.; Fodstad, O.; Tan, M. Upregulation of lactate dehydrogenase A by ErbB2 through heat shock factor 1 promotes breast cancer cell glycolysis and growth. Oncogene 2009, 28, 3689-3701. [CrossRef] [PubMed]

43. Kabakov, A.E.; Makarova, Y.M.; Malyutina, Y.V. Radiosensitization of human vascular endothelial cells through Hsp90 inhibition with 17-N-allilamino-17-demethoxygeldanamycin. Int. J. Radiat. Oncol. Biol. Phys. 2008, 71, 858-865. [CrossRef] [PubMed]

44. Bisht, K.S.; Bradbury, C.M.; Mattson, D.; Kaushal, A.; Sowers, A.; Markovina, S.; Ortiz, K.L.; Sieck, L.K.; Isaacs, J.S.; Brechbiel, M.W.; et al. Geldanamycin and 17-allylamino-17-demethoxygeldanamycin potentiate the in vitro and in vivo radiation response of cervical tumor cells via the heat shock protein 90-mediated intracellular signaling and cytotoxicity. Cancer Res. 2003, 63, 8984-8995. [PubMed]

45. Enmon, R.; Yang, W.H.; Ballangrud, A.M.; Solit, D.B.; Heller, G.; Rosen, N.; Scher, H.I.; Sgouros, G. Combination treatment with 17-N-allylamino-17-demethoxy geldanamycin and acute irradiation produces supra-additive growth suppression in human prostate carcinoma spheroids. Cancer Res. 2003, 63, 8393-8399. [PubMed]

46. Machida, H.; Matsumoto, Y.; Shirai, M.; Kubota, N. Geldanamycin, an inhibitor of Hsp90, sensitizes human tumour cells to radiation. Int. J. Radiat. Biol. 2003, 79, 973-980. [CrossRef]

47. Russell, J.S.; Burgan, W.; Oswald, K.A.; Camphausen, K.; Tofilon, P.J. Enhanced cell killing induced by the combination of radiation and the heat shock protein 90 inhibitor 17-allylamino-17- demethoxygeldanamycin: A multitarget approach to radiosensitization. Clin. Cancer Res.: Off. J. Am. Assoc. Cancer Res. 2003, 9, 3749-3755.

48. Bull, E.E.; Dote, H.; Brady, K.J.; Burgan, W.E.; Carter, D.J.; Cerra, M.A.; Oswald, K.A.; Hollingshead, M.G.; Camphausen, K.; Tofilon, P.J. Enhanced tumor cell radiosensitivity and abrogation of G2 and S phase arrest by the Hsp90 inhibitor 17-(dimethylaminoethylamino)-17-demethoxygeldanamycin. Clin. Cancer Res.: Off. J. Am. Assoc. Cancer Res. 2004, 10, 8077-8084. [CrossRef]

49. Harashima, K.; Akimoto, T.; Nonaka, T.; Tsuzuki, K.; Mitsuhashi, N.; Nakano, T. Heat shock protein 90 (Hsp90) chaperone complex inhibitor, radicicol, potentiated radiation-induced cell killing in a hormone-sensitive prostate cancer cell line through degradation of the androgen receptor. Int. J. Radiat. Biol. 2005, 81, 63-76. [CrossRef]

50. Dote, H.; Burgan, W.E.; Camphausen, K.; Tofilon, P.J. Inhibition of hsp90 compromises the DNA damage response to radiation. Cancer Res. 2006, 66, 9211-9220. [CrossRef] 
51. Eccles, S.A.; Massey, A.; Raynaud, F.I.; Sharp, S.Y.; Box, G.; Valenti, M.; Patterson, L.; de Haven Brandon, A.; Gowan, S.; Boxall, F.; et al. NVP-AUY922: A novel heat shock protein 90 inhibitor active against xenograft tumor growth, angiogenesis, and metastasis. Cancer Res. 2008, 68, 2850-2860. [CrossRef] [PubMed]

52. Chinnaiyan, P.; Allen, G.W.; Harari, P.M. Radiation and new molecular agents, part II: Targeting HDAC, HSP90, IGF-1R, PI3K, and Ras. Semin. Radiat. Oncol. 2006, 16, 59-64. [CrossRef] [PubMed]

53. Matsumoto, Y.; Machida, H.; Kubota, N. Preferential sensitization of tumor cells to radiation by heat shock protein 90 inhibitor geldanamycin. J. Radiat. Res. 2005, 46, 215-221. [CrossRef]

54. Machida, H.; Nakajima, S.; Shikano, N.; Nishio, J.; Okada, S.; Asayama, M.; Shirai, M.; Kubota, N. Heat shock protein 90 inhibitor 17-allylamino-17-demethoxygeldanamycin potentiates the radiation response of tumor cells grown as monolayer cultures and spheroids by inducing apoptosis. Cancer Sci. 2005, 96, 911-917. [CrossRef] [PubMed]

55. Dote, H.; Cerna, D.; Burgan, W.E.; Camphausen, K.; Tofilon, P.J. ErbB3 expression predicts tumor cell radiosensitization induced by Hsp90 inhibition. Cancer Res. 2005, 65, 6967-6975. [CrossRef] [PubMed]

56. Kelland, L.R.; Sharp, S.Y.; Rogers, P.M.; Myers, T.G.; Workman, P. DT-Diaphorase expression and tumor cell sensitivity to 17-allylamino, 17-demethoxygeldanamycin, an inhibitor of heat shock protein 90. J. Natl. Cancer Inst. 1999, 91, 1940-1949. [CrossRef] [PubMed]

57. Eiseman, J.L.; Lan, J.; Lagattuta, T.F.; Hamburger, D.R.; Joseph, E.; Covey, J.M.; Egorin, M.J. Pharmacokinetics and pharmacodynamics of 17-demethoxy 17-[[(2-dimethylamino)ethyl]amino]geldanamycin (17DMAG, NSC 707545) in C.B-17 SCID mice bearing MDA-MB-231 human breast cancer xenografts. Cancer Chemother. Pharmacol. 2005, 55, 21-32. [CrossRef]

58. Brough, P.A.; Aherne, W.; Barril, X.; Borgognoni, J.; Boxall, K.; Cansfield, J.E.; Cheung, K.M.; Collins, I.; Davies, N.G.; Drysdale, M.J.; et al. 4,5-diarylisoxazole Hsp90 chaperone inhibitors: Potential therapeutic agents for the treatment of cancer. J. Med. Chem. 2008, 51, 196-218. [CrossRef]

59. Jensen, M.R.; Schoepfer, J.; Radimerski, T.; Massey, A.; Guy, C.T.; Brueggen, J.; Quadt, C.; Buckler, A.; Cozens, R.; Drysdale, M.J.; et al. NVP-AUY922: A small molecule HSP90 inhibitor with potent antitumor activity in preclinical breast cancer models. Breast Cancer Res.: Bcr 2008, 10, R33. [CrossRef]

60. Schilling, D.; Kühnel, A.; Tetzlaff, F.; Konrad, S.; Multhoff, G. NZ28-induced inhibition of HSF1, SP1 and NF-kappaB triggers the loss of the natural killer cell-activating ligands MICA/B on human tumor cells. Cancer Immunol. Immunother.: Cii 2015, 64, 599-608. [CrossRef]

61. Chen, Y.; Chen, J.; Loo, A.; Jaeger, S.; Bagdasarian, L.; Yu, J.; Chung, F.; Korn, J.; Ruddy, D.; Guo, R.; et al. Targeting HSF1 sensitizes cancer cells to HSP90 inhibition. Oncotarget 2013, 4, 816-829. [CrossRef] [PubMed]

62. Kudryavtsev, V.A.; Khokhlova, A.V.; Mosina, V.A.; Selivanova, E.I.; Kabakov, A.E. Induction of Hsp70 in tumor cells treated with inhibitors of the Hsp90 activity: A predictive marker and promising target for radiosensitization. PLoS ONE 2017, 12, e0173640. [CrossRef] [PubMed]

63. Gandhi, N.; Wild, A.T.; Chettiar, S.T.; Aziz, K.; Kato, Y.; Gajula, R.P.; Williams, R.D.; Cades, J.A.; Annadanam, A.; Song, D.; et al. Novel Hsp90 inhibitor NVP-AUY922 radiosensitizes prostate cancer cells. Cancer Biol. Ther. 2013, 14, 347-356. [CrossRef] [PubMed]

64. Noguchi, M.; Yu, D.; Hirayama, R.; Ninomiya, Y.; Sekine, E.; Kubota, N.; Ando, K.; Okayasu, R. Inhibition of homologous recombination repair in irradiated tumor cells pretreated with Hsp90 inhibitor 17-allylamino-17-demethoxygeldanamycin. Biochem. Biophys. Res. Commun. 2006, 351, 658-663. [CrossRef] [PubMed]

65. Hosokawa, N.; Hirayoshi, K.; Kudo, H.; Takeshi, H.; Aoike, A.; Kawai, K.; Nagata, K. Inhibition of the activation of heat shock factor in vivo and in vitro by flavonoids. Mol. Cell Biol. 1992, 12, 3490-3498. [CrossRef]

66. Yokota, S.; Kitahra, M.; Nagata, K. Benzylidene lactam compound KNK437 a novel inhibitor of acquisition of thermotolerance and heat shock protein induction in human colon carcinoma cells. Cancer Res. 2000, 60, 2942-2948. [PubMed]

67. Westerheide, S.D.; Kawahara, T.L.A.; Orton, K.; Morimoto, R.I. Triptolide, an inhibitor of the human heat shock response that enhances stress-induced cell death. J. Biol. Chem. 2006, 281, 9616-9622. [CrossRef] 
68. Lazarev, V.F.; Sverchinsky, D.V.; Mikhaylova, E.R.; Semenyuk, P.I.; Komarova, E.Y.; Niskanen, S.A.; Nikotina, A.D.; Burakov, A.V.; Kartsev, V.G.; Guzhova, I.V.; et al. Sensitizing tumor cells to conventional drugs: Hsp70 chaperone inhibitors, their selection and application in cancer models. Cell Death Dis. 2018, 9 , 41. [CrossRef] [PubMed]

69. Nikotina, A.D.; Koludarova, L.; Komarova, E.Y.; Mikhaylova, E.R.; Aksenov, N.D.; Suezov, R.; Kartzev, V.G.; Margulis, B.A.; Guzhova, I.V. Discovery and optimization of cardenolides inhibiting HSF1 activation in human colon HCT-116 cancer cells. Oncotarget 2018, 9, 27268-27279. [CrossRef]

(C) 2019 by the authors. Licensee MDPI, Basel, Switzerland. This article is an open access article distributed under the terms and conditions of the Creative Commons Attribution (CC BY) license (http://creativecommons.org/licenses/by/4.0/). 